\title{
Access and Equity in Basic Education
}

\author{
Dr. Saqib Shahzad \\ Institute of Education \& Research \\ University of Science \& Technology, Bannu, (NWFP) Pakistan \\ Tel: 92-0928-621101Ｅ-mail: drsaqib577@yahoo.com
}

Riasat Ali (Corresponding author)

Institute of Education \& Research

University of Science \& Technology, Bannu, (NWFP) Pakistan

Tel: 92-0928-621101_E-mail: drriasatali@yahoo.com

Hukamdad

Department of Education

National University of Modern Languages Islamabad, Pakistan

Tel: 92-0346-9186014 E-mail: drhukamdad@gmail.com

Safdar Rehman Ghazi

Institute of Education \& Research

University of Science \& Technology, Bannu, (NWFP) Pakistan

Tel: 92-0928-621101Ｅ-mail: drsrghazi@yahoo.com

Ms. Uzma Syeda Gilani

Institute of Education \& Research

University of Science \& Technology, Bannu, (NWFP) Pakistan

Tel: 92-0928-621101Ｅ-mail: uzmasyedagilani@yahoo.com

\begin{abstract}
Education is the key to development in any society. It is also true to say that the condition of the educational institution in any given society reflects the standard of living and the attitudes towards life of that society. The major purpose of this study was to investigate the access and equity in basic education in Northern. The main objectives of the study were: To assess the extent of availability of primary level schools in West Frontier Province. To compare the reasons of repetition and dropout rates among children at primary level. To understand the views of teachers and parents regarding access and equity in basic education. To recommend some measures for the improvement of basic education in West Frontier Province. Two questionnaires, one for teacher and for parents were administered to collect data. The collected data were tabulated, analyzed and interpreted in the light of objectives of the studies. In the light of conclusions it is recommended that more primary schools should be established for reducing distance from home to school for small children particularly in rural area. Moreover, maximum physical facilities may be provided. Measures should be taken to reduce gender disparity in West Frontier Province. Syllabus may be revised and developed according to the mental level and requirements of the students. Education may be made cheap/free and trained/qualified teachers may be appointed wherever needed.
\end{abstract}

Keywords: Basic education, Access and equity, Dropout, Primary level 


\section{Introduction}

The education is a basic right of each individual. Provision of educational facilities and education to all its masses is the obligation of society in social perspective of the society. Education is directly related to the development of the society. Education system provide trained skilled, and semi skilled manpower to the society on one hand and on the other hand it provide sound footing to higher education. Education system performs these two functions side by side. Currently in Pakistan three tier system of education is followed i.e. Elementary, Secondary and Higher education system. The strength or weakness of each one affects the quality of other. Basic education system and its infrastructure is very prominent, if it has shortcomings, it badly affect the quality or smooth flow of adjacent upper stage (Govt of Pakistan, 1979).

There is, in each and every child, irrespective of his parent age and his place of birth, a divine fire, the will to know and learn, to experiment and discover which part of the will to grow and live is. This divine fire can carry the child to manhood, and, if kept alive, can sustain the child in the man. This is the soul of education, which can inspire the child to limitless heights of learning, ever-widening circles of knowledge, and infinitely exciting journeys into the world of ideas (Ayub, 2000).

Discussing the significance of education, Bhatti (1987) cited that Aristotle viewed as "educated men are as much superior to uneducated as the living are to the dead". It is universally accepted that education is a concomitant of all human societies. Considering the importance of education for mankind, a world forum consisting of UN agencies, World Bank and NGOs joined hands and a World Conference on Education for All was held in Thailand, in March 1990. All the nations of the world adopted a world declaration on "Education for All." The declaration included that "education is a fundamental right for all people' women and men of all ages, throughout the world".

Education is a fundamental human right. It is the key to sustainable development, peace and stability within and among countries, and thus an indispensable means for effective participation in the societies and economics of the twenty-first century, which are affected by rapid globalization. Achieving EFA goals may not be postponed any more. The basic learning needs of all can and must be met as a matter of urgency (UNESCO, 2000).

The study was designed to explore the problems and issues of access and equity in basic education. Massive expansion of educational facilities during the last two decades has resulted tremendous increase in enrolment in schools. In spite of the expansion, a number of primary age children are still out of school, especially girls. The number of adult illiterates in the country was about 43 million in 1981 with $26 \%$ literacy rate; the absolute number of illiterates was around 53 million in 1998 with $45 \%$ literacy rate (an increase of 10 million illiterates). The increase in the number of illiterates suggests that a number of children especially girls do not have access to school and those who get enrolled in school, drop out before completing primary cycle. The issue of equity in terms of the quality of education such as physical facilities in schools, academic and professional qualification of teaching staff and teaching learning materials has been a matter of concern for the policy makers and planners (Raheela, 2001).

The educational system in Pakistan today is riddled with problems. But the gigantic problem, which overshadows all others, is the lack of facilities, shortage of schools, and the non-existence of any kind of schooling, even on the primary level, especially in rural areas. The crying need in Pakistan today is for universal, compulsory primary education. This is so obvious that one is almost ashamed to repeat it. And yet, it is my firm belief that it has to be said, again and again, until whatever government is in power, on national and provincial levels, has no choice but to listen and implements, giving the provision of universal, compulsory primary education priority over all other programs (Shami, 2004).

The percentage of literacy in Pakistan is one of the lowest among the under-developed countries of the world. $70 \%$ to $80 \%$ of our population receives no formal education at all; only the educating experience of life in the fields and narrow, muddy village lanes, and in the equally narrow and smellier alleys in the congested city slums. Of the remaining $20 \%$ to $30 \%$, the lucky minority who do manage to get some formal education, the education offered to them in our schools is often more limiting than the informal education naturally offered at home and in the streets and fields. Children sit in rows in overcrowded classrooms and they are told to memorize passages from text-books which have no meaning for them, no relevance relatable to life as they know it.

There is nothing more important in the lives of individuals, families, nations and communities of nations than education. And yet, teaching is one of the poorest paid professions. It is the job that our weakest graduates fall back on. It is the privileged section of the community, those who have enjoyed the benefits of education and who can afford to educate their children too, who are, in the ultimate analysis, responsible to extend the scope of the benefits of education, it include the whole of the population. Unless and until the privileged section of society begins to take their responsibilities in the field of education seriously, and give priority to motivating and 
keeping some of the cream of our graduates in the sphere of education, by giving them proper remuneration, our children will not fulfill their potential on either the personal and private, or public and social levels (Ghafoor, 1990).

\section{Method and Procedure}

The major purpose of the study was to investigate the causes of low access and equity in basic education. The study was descriptive in nature. All the teachers and parents of the students at primary level of Northern West Frontier Province were taken as population of the study. Sample was selected randomly. Two hundred Teachers and parents from Northern West Frontier Province will be selected as sample of the study. Two questionnaires, one each for teachers and parents were developed for the collection of necessary data. The questionnaires were validated through pilot testing before these were administered on the sample. Data was collected through administering the questionnaires validated through the pilot testing. For that purpose, the researcher visited all the sample institutions and respondents personally. Data collected through the above-mentioned research instruments were tabulated, analyzed and interpreted through simple percentage in the light of the objectives of the study.

\section{Data Analysis}

The study was aimed at investigating the causes of low enrollment in basic education. The data collected through research instruments were tabulated analyzed and interpreted in the light of the objectives of the study. Results are being presented in the following lines.

\section{Conclusions}

In the light of statistical analysis and findings of the study, the following conclusions were drawn.

- Majority of the respondents were of the opinion that Schools were not being properly mapped.

- Maximum sample respondents opined that economic problems are the major cause of low enrollment in basic education.

- Maximum responds were of view that no proper guidance is provided to the children at home.

- Majority of the respondents reported that physical facilities were not properly available in most of the institutions.

- Majority of the respondents were of the opinion that the syllabus was difficult.

- Majority of the respondents reported that unattractive environment is the major cause of low enrolment in basic education.

- Maximum sample respondents opined that majority of the parents are illiterate.

- Majority of the respondents were of the opinion that in-service training was properly provided to the teachers.

- It was concluded from the findings of study that poverty is the major cause of low enrollment.

\section{Recommendations}

In the light of conclusions following recommendations were drawn

- It is recommended that more primary schools are to be established for reducing distance from home to school for small children particularly in rural area. Moreover, maximum physical facilities may be provided.

- It is recommended that measures should be taken to reduce gender disparity in district Bannu.

- Syllabus may be revised and developed according to the mental level and requirements of the students. So that they take interest in studies.

- Education may be made cheap/free.

- $\quad$ Trained/qualified teachers may be appointed wherever needed. The training should include the dealing with small children with decent and encouraging behaviors.

\section{References}

Ayub, F. (2000). A study of measuring student achievement in relation to parents' involvement. Thesis: Master in education. Fatima Jinnah Women University Rawalpindi.

Bhatti, M. A. (1987). Primary Education improvement: desired measures, NEC, Islamabad. Pakistan. pp 44. 
Ghafoor, A. (1990). "Primary Education in Pakistan” AEPAM, Islamabad, Pakistan. P33.

Govt of Pakistan, (1979). National Education Policy. Ministry of Education, Islamabad Pakistan. pp 32.

Reheela, B. (2001). An investigation into the Factors of low enrollment Ratio of Girls in Elementary schools of Rawalpindi district, thesis of Philosophy in education, Allama Iqbal Open University. Islamabad pp 185-188.

Shami, P. A. (2004). National Sample Survey of Private School Academy of Educational Planning and Management Islamabad, pp 33.

UNESCO. (2000). National Conference Report on Education for All, Islamabad, pp 44.

Table 1. Reason given by parents for not enrolling their children in school

\begin{tabular}{|c|l|c|c|c|c|c|}
\hline $\begin{array}{c}\text { S.N } \\
\text { o. }\end{array}$ & \multicolumn{1}{|c|}{ Reason for not enrolling } & (Yes) & \% & (No) & \% & Total \\
\hline 1 & Schools are not available & 124 & 62 & 76 & 38 & 200 \\
\hline 2 & Education is too expensive & 108 & 54 & 92 & 46 & 200 \\
\hline 3 & Lack of guidance at home & 96 & 48 & 104 & 52 & 200 \\
\hline 4 & Making earning for the family & 102 & 51 & 98 & 49 & 200 \\
\hline 5 & Security problems & 121 & 60.5 & 79 & 39.5 & 200 \\
\hline 6 & Teacher's absenteeism & 101 & 50.5 & 99 & 49.5 & 200 \\
\hline 7 & Non availability of books & 72 & 36 & 128 & 64 & 200 \\
\hline 8 & Willingness of children & 111 & 55.5 & 89 & 44.5 & 200 \\
\hline 9 & Availability of basic facilities & 89 & 44.5 & 111 & 55.5 & 200 \\
\hline
\end{tabular}

The table no1 reveals that $62 \%$ parents considered that non availability of school is the major cause for not enrolling their children in schools. $61 \%$ parents agree that security problem was the reason for not enrolling their children in schools. Similarly $54 \%$ parents though that education is too expensive. Furthermore $51 \%$ parents reported that poverty was the major reason for not enrolling their children in schools.

Table 2. Reason offered by parents about their children leaving school

\begin{tabular}{|c|l|c|c|c|c|c|}
\hline $\begin{array}{c}\text { S.N } \\
\text { o. }\end{array}$ & $\begin{array}{l}\text { Reason of leaving the school at primary } \\
\text { level }\end{array}$ & (Yes) & $\mathbf{\%}$ & $\mathbf{( N o )}$ & $\mathbf{\%}$ & Total \\
\hline 1 & To much distance of school from home & 83 & 41.5 & 117 & 58.5 & 200 \\
\hline 2 & Teacher's harsh behavior & 104 & 52 & 96 & 48 & 200 \\
\hline 3 & Lack of interest of parents & 99 & 49.5 & 101 & 50.5 & 200 \\
\hline 4 & Large family size & 117 & 58.5 & 83 & 41.5 & 200 \\
\hline 5 & Lack of competent teachers & 116 & 58 & 84 & 42 & 200 \\
\hline 6 & Uninteresting syllabus & 94 & 47 & 106 & 53 & 200 \\
\hline 7 & Physical punishment & 120 & 60 & 80 & 40 & 200 \\
\hline 8 & Illiterate parents & 115 & 57.5 & 85 & 42.5 & 200 \\
\hline 9 & Shortage of professional trained teacher & 109 & 54.5 & 96 & 55.5 & 200 \\
\hline 10 & Poverty & 135 & 67.5 & 65 & 32.5 & 200 \\
\hline
\end{tabular}

The table- 2 mentions that $68 \%$ parents considered the poverty was an important factor for children to leave the school. $60 \%$ parents thought that physical punishment were the reason for leaving school. $59 \%$ parents thoughts that large family size was important reason of boys leaving the school. Similarly $55 \%$ parents thought lack of competent teacher was the reason for leaving the school. Further more 58\% parents thought illiterate parents are important reason of school leaving for boys. For 55\% parents reported that, another reason of leaving school for boys' shortage of professional trained teachers and 52\% parents mentions harsh behavior teacher. 
Table 3. Family related factor for children not enrolling in school

\begin{tabular}{|c|l|c|c|c|c|c|}
\hline S.No. & \multicolumn{1}{|c|}{ Family related factors } & (Yes) & & (No) & \% & Total \\
\hline 1 & Unattractive environment & 120 & 60 & 80 & 40 & 100 \\
\hline 2 & Support in household work & 116 & 58 & 84 & 42 & 100 \\
\hline 3 & Child sickness & 81 & 40.5 & 119 & 59.5 & 100 \\
\hline 4 & Lack of encouragement at home & 119 & 59.5 & 81 & 40.5 & 100 \\
\hline 5 & Unavailability of Form-B & 80 & 40 & 120 & 60 & 100 \\
\hline
\end{tabular}

Above table mentioned that $60 \%$ parents thoughts that unattractive environment was the major cause of not enrolling their children's I schools. $60 \%$ respondents said that lack of encouragement at home was the reason for not enrolling the boys. $58 \%$ parents support in household work in the reason for leaving the school.

Table 4. School related factor for not enrolling children in school

\begin{tabular}{|c|l|c|c|c|c|c|}
\hline S.No. & $\begin{array}{l}\text { School related factors for not } \\
\text { enrolling children in school }\end{array}$ & (Yes) & $\mathbf{\%}$ & (No) & Total & T \\
\hline 1 & Non availability of school building & 82 & 41 & 118 & 59 & 200 \\
\hline 2 & Difficult syllabus & 120 & 60 & 80 & 40 & 200 \\
\hline 3 & Repeated failure & 103 & 51.5 & 97 & 48.5 & 200 \\
\hline 4 & Not availability of drinking water & 87 & 43.5 & 113 & 56.5 & 200 \\
\hline 5 & Lack of facility toilet & 116 & 58 & 84 & 42 & 200 \\
\hline
\end{tabular}

It is evident from the above table no 4 that $60 \%$ respondents reported that difficult syllabus was the major cause of less enrollment in schools. Furthermore 58\% respondents thought that lack of basic facilities was the major cause of fewer enrollments.

Table 5. Reason given by teacher for not enrolling their children in school

\begin{tabular}{|c|l|c|c|c|c|c|}
\hline S.No. & \multicolumn{1}{|c|}{ Reason for not enrolling boys } & (Yes) & & (No) & & Total \\
\hline 1 & Available of school & 118 & $59 \%$ & 82 & $41 \%$ & 200 \\
\hline 2 & Education is too expensive & 97 & $48.5 \%$ & 103 & $51.5 \%$ & 200 \\
\hline 3 & Provision of help at home & 106 & $53 \%$ & 94 & $47 \%$ & 200 \\
\hline 4 & Making earning for the family & 88 & $44 \%$ & 112 & $56 \%$ & 200 \\
\hline 5 & Security problems & 113 & $56.5 \%$ & 87 & $43.5 \%$ & 200 \\
\hline 6 & Teacher's absenteeism & 105 & $52.5 \%$ & 95 & $47.5 \%$ & 200 \\
\hline 7 & Too much distance of school from & 70 & $35 \%$ & 130 & $65 \%$ & 200 \\
\hline 8 & home & 116 & $58 \%$ & 84 & $42 \%$ & 200 \\
\hline 9 & Availlingness of children & 87 & $43.5 \%$ & 113 & $56.5 \%$ & 200 \\
\hline
\end{tabular}

The data in table-5 indicates that the highest percentage of $68 \%$ teachers said that non availability of school was very important reason for not enrolling the school. For $66 \%$ teacher said that willingness of children was a reason of children from dropout of school. It is important that $63 \%$ teachers said that security problems were important reason of dropout of children from school. Similarly $56 \%$ teachers considered provision of help at home as a reason for children dropout from school. 55\% teacher's thoughts teachers' absenteeism is the reason of dropout of the children from school. 
Table 6. Reason offered by teachers about leaving school

\begin{tabular}{|c|l|c|c|c|c|c|}
\hline S.No. & \multicolumn{1}{|c|}{ Reason for leaving school } & (Yes) & & (No) & \% & Total \\
\hline 1 & Excessive home work & 90 & 45 & 110 & 55 & 200 \\
\hline 2 & Teachers harsh behavior & 88 & 44 & 112 & 56 & 200 \\
\hline 3 & Lack of interest of parents & 119 & 59.5 & 81 & 40.5 & 200 \\
\hline 4 & Large family size & 102 & 51 & 98 & 49 & 200 \\
\hline 5 & Lack of competent teachers & 110 & 55 & 90 & 45 & 200 \\
\hline 6 & On interesting syllabus & 107 & 53.5 & 83 & 46.5 & 200 \\
\hline 7 & Physical punishment & 93 & 46.5 & 107 & 52.5 & 200 \\
\hline 8 & Illiterate parents & 131 & 65.5 & 69 & 34.5 & 200 \\
\hline 9 & $\begin{array}{l}\text { Shortage of professionally parent } \\
\text { teachers }\end{array}$ & 104 & 52 & 96 & 48 & 200 \\
\hline 10 & Poverty & 126 & 63 & 74 & 37 & 200 \\
\hline
\end{tabular}

It is evident from the above table- 6 that $81 \%$ teacher took illiterate parents was an important reason for children to leaving the school. $76 \%$ teachers considered poverty as important reasons for boys to leave the school. $69 \%$ teachers had the opinion that lack of interest of parents was an important reason for the boys to leave the school. Similarly, for $57 \%$ teachers, it was on interesting syllabus. Many other reasons for school leaving included lack of competent teachers, shortage of professionally trained teachers and large family size etc.

Table 7. Physical facilities at primary level

\begin{tabular}{|c|l|c|c|c|c|c|}
\hline S.No. & \multicolumn{1}{|c|}{ Facility } & (Yes) & $\mathbf{\%}$ & $\mathbf{( N o )}$ & $\mathbf{\%}$ & Total \\
\hline 1 & Drinking water & 95 & 47.5 & 105 & 52.5 & 200 \\
\hline 2 & Electricity & 89 & 44.5 & 111 & 55.5 & 200 \\
\hline 3 & Toilet & 99 & 49.5 & 101 & 50.5 & 200 \\
\hline 4 & Furniture & 85 & 42.5 & 115 & 56.5 & 200 \\
\hline 5 & Playground & 86 & 43 & 114 & 57 & 200 \\
\hline 6 & Library & 77 & 38.5 & 123 & 61.5 & 200 \\
\hline
\end{tabular}

The above table shows that basic physical facilities were not properly available in majority of the primary schools and this is the major cause of low access of children towards education 